\title{
An information system for heritage documentation management of Cuenca city, Ecuador
}

\author{
Verónica Heras B. ${ }^{I}$, Thérèse Steenberghen ${ }^{2}$, Marcelo Zúñiga ${ }^{1}$, Fausto Cardoso ${ }^{1}$, Mario Santana \\ $Q^{3}$, , Koenraad Van Balen ${ }^{4}$ \\ ${ }^{1}$ Faculty of Architecture, University of Cuenca, Cuenca, Ecuador \\ ${ }^{2}$ Division SADL, Katholieke Universiteit Leuven, Leuven, Belgium \\ ${ }^{3}$ Department of Architecture, Urban Design and Regional Planning, Katholieke Universiteit Leuven, \\ Leuven, Belgium \\ ${ }^{4}$ Centrum voor Monumentenzorg, Katholieke Universiteit Leuven, Leuven, Belgium \\ Corresponding author: veronicaheras@gmail.com
}

Fecha de recepción: 19 de abril 2012 - Fecha de aceptación: 17 de julio 2012

\begin{abstract}
The understanding and safeguarding of Cultural Heritage involves the collection, storage and processing of all forms of relevant information pertaining to it. Whereas the heterogeneous sets of data help understanding the heritage monument or site; heritage data management is an essential task for the use, dissemination, protection and conservation of the monuments. Compiling heritage monument records is still mostly a manual procedure, while computer technology partially solved data organization and archiving of individual components. Additionally, a main bottle neck for the archiving of heritage information of sites belonging to the World Heritage List is that information is collected and archived by a variety of institutions and that each archiving organization has its own protocol and tradition of data storage and dissemination. To integrate the dispersed available information, which would facilitate the retrieval of information and making the information available for decision-making, this paper presents a concept of Heritage Information System (HIS) based on: (i) value-based assessment at different scales, (ii) a heritage (geo) database, and (iii) a geographic information system (GIS). For the development of the concept heritage data of the historic city of Cuenca (World Heritage Site, 1999), Ecuador, were used.
\end{abstract}

Keywords: Cultural heritage site, data management, heritage information system, GIS, value-based assessment, Historic Center of Cuenca.

\section{RESUMEN}

La comprensión y la salvaguarda del Patrimonio Cultural edificado implican la recolección, almacenamiento y procesamiento de todo tipo de información relativa a él. Si se considera que este conjunto heterogéneo de datos nos ayuda a conocer profundamente el monumento o sitio patrimonial, la gestión de estos datos, resulta una tarea esencial para su difusión, protección y conservación. En diferentes sitios patrimoniales, la recolección de los registros y datos es todavía parte de procedimientos manuales en donde la tecnología informática ha resuelto parcialmente la organización y archivo de datos. Sin embargo, otro problema persiste en la forma de estructuración y archivo de información sobre sitios patrimoniales, en donde diferentes Instituciones al cuidado y conservación, carecen de protocolos establecidos en el almacenamiento y su posterior difusión. De este modo, este trabajo de investigación nace de la necesidad de integrar la información dispersa, apoyando y asistiendo la toma de decisiones para la conservación patrimonial. Este artículo presenta un concepto de Sistema de información Patrimonial (HIS), basado en: (i) compresión del valor patrimonial a diferentes escalas, (ii) el uso de una base de datos geográfica, y (iii) un sistema de información geográfica (SIG); elementos usados en el desarrollo de un sistema de información patrimonial de la ciudad de Cuenca (Patrimonio de la Humanidad 1999). 
Palabras clave: Sitio patrimonial, gestión de datos, sistema de información patrimonial, SIG, Evaluación basada en valores, Centro Histórico de Cuenca.

\section{HERITAGE DATA MANAGEMENT: CUENCA CITY}

Conservation of cultural sites has traditionally been focused on the protection and restoration of existing monuments and buildings, but nowadays the challenge of heritage conservation is moving towards the preservation through preventive monitoring and maintenance based strategies (PRECOMOS, 2007 and 2010). These concepts are not new, they were presented and adopted in 1931 at the First International Congress of Architects and Technicians of Historic Monuments in Athens (ICOMOS, 1964), and as a function of needs and new insights further improved in subsequent international charters. Preventive conservation presents advantages as well as challenges. In a strict sense, it keeps the intervention at a minimum, ensuring the integrity, reducing long term heritage losses and the financial burden for all stakeholders (Meul and Stulens, 2010). Meeting the concept of preventive conservation in the city of Cuenca, inscribed on the World Heritage List in 1999, requires the availability of accurate information on the type, status and cultural value of the numerous heritage monuments present in the city. In addition, from a preventive conservation perspective, this implies indicators of material degradation, documentation of (in)adequacy of technical interventions, among other factors such as risk analysis.

With respect to the heritage information, the city of Cuenca has access to four inventories, respectively compiled in the periods: 1975 - 1978, 1980 - 1982, 1999 and 2010. Due to the extent of the heritage assets of the city, the information is vast and very variable. The difference in methods and techniques of data collection and the intellectual property rights claimed by each heritage data collecting department (e.g. the Historic and Heritage Department, Cadastral Department, Control Department, etc.), even if belonging to the same institution (e.g. the municipality), strongly hinders the efficient and optimal use of the available heritage information. Differences in the approach and the type of collected data are according to Santana-Quintero and Addison (2007) due to:

$\checkmark$ The non-existence of standard procedures for data collection, the difference in the way heritage information is referenced and stored, and the variety of used techniques for data collection and storage (Letellier, 2007). All these factors strongly contribute to the heterogeneity and incompatibility of collected heritage information.

$\checkmark$ The lack and/or non-existence of communication and openness on sharing heritage information between the data collectors (the National Institute of Cultural Heritage, the Municipality, and the different departments of the Universities) and stakeholders resulted in effort duplication and the inefficient use of financial resources.

$\checkmark$ The use of different commercial software hinders the accessibility and the integration of the variety of information between stakeholders.

$\checkmark$ The inexistence of measures to secure, archive and systematically update information, something highly important when dealing with digital information.

$\checkmark$ The interoperability problems between the available data systems of the city of Cuenca.

In summary, for the city of Cuenca and many other cities with rich cultural heritage but situated in less developed and economic emerging countries, the dispersion of heritage information and the way data are stored and handled clearly demonstrate the inefficient use of the scarce financial resources for the management of heritage information. In addition to standardization of procedures, more costeffective data collection and processing requires clear guidelines of "who", "what" and "how" heritage data have to be gathered and stored in a powerful data management system. Doing so enables an easy retrieval and data processing for a variety of applications and analyses in support of decisionmaking.

To improve the future preservation and conservation of the heritage richness of the city of Cuenca, this paper presents a conceptual model of a Heritage Information System (HIS). The starting 
hypothesis of the HIS is the systems availability to handle large amounts of heritage information collected and to be processed at different scales, varying from the city scale to minor scales of a heritage building. The introduction of a top down approach will enable the spatial location of heritage monuments in a wider archaeological context and the integration of details in a larger geo-scale, as often applied in archaeological studies. The final goal of the HIS is improving the management of the city's heritage property under a preventive conservation approach (Bansal and Pal, 2009).

\section{STATE-OF-THE-ART OF HERITAGE INFORMATION SYSTEMS}

To surpass the possible connotation with geo-localized data, the concept on which geographic information systems (GIS) are based, in this research the term Information System (IS) was selected as to underline that in addition to the geo-localization of heritage sites, the main emphasis is on the attribute data of the site. According to Meyer et al. (2007) an Information System stands for a combination of diverse types of data (recorded in databases) accessible through an interface proposed by the system. The quality of this system can be estimated by its capacity to manage and present information in a useful and efficient way. However, the main emphasis for the current research is on how to make such a system useful for the management of heritage information, therefore it is important to consider the theoretical overview of heritage management inferences in association with the IS.

In light to previous a good overview on the management of heritage sites was given by SantanaQuintero and Addison (2007). Their paper reflects the importance of good decisions in conservation, which fundamentally requires the availability of appropriate information. In this regard, digital tools and information systems might help with the storage and retrieval of relevant information, the processing of this information for a more adequate and coherent management of cultural heritage, and the presentation of this information in public exhibitions, vulgarization leaflets and scientific documents (Santana-Quintero and Addison, 2007). Moreover, different publications presented during the International Symposium on Heritage Recording \& Information Management in the Digital Age (SMARTDoc Heritage) held in Philadelphia, USA, in 2010, and summarized in the Heritage Journal "Change over Time" (Santana-Quintero and Vileikis, 2011), state that IS in the field of heritage mainly is used for the monitoring of archaeological sites and the management of landscape applications. This explains that IS in most projects is used for the management of large scale data, rather than at small scales as for example historic buildings for the storage, retrieval and management of constitutive elements such as walls, structures, architectural decorations, etc. Recently, important database developments for the storage, processing and management of small scale heritage information were made by the Politecnico di Milano (Italy) and Monumentenwacht (Belgium). The latter is a Flemish non-governmental institution with the mission to empower, stimulate, inform and support its members (owners, managers and custodians) to care for and preserve their cultural heritage. The institution started in 2007 with the development of the database MAKSin (Meul and Stulens, 2010) to facilitate the recording and reporting of cultural and historic heritage information (Stulens, 2000). Whereas the database is continuously improved by incorporating new fields and evaluation parameters, the IS for the processing and analysis of data has not yet been developed. In this context, this paper presents a concept of Heritage Information System applied to heritage data of the city of Cuenca, which, after physical implementation, could constitute a useful tool for the heritage management of World Heritage Sites.

\section{A HERITAGE INFORMATION SYSTEM FOR CUENCA'S HISTORIC CITY CENTRE}

To develop a system of good quality, usefulness and efficiency need to be ensured. A use-based approach is therefore preferred to a data-driven or a software-driven approach. This implies understanding of heritage information requirements and questions. The strategy followed for the development of the conceptual HIS is guided by the following two principles: (i) consultation of the 
stakeholders (the users of the system) to account for their interest and needs, and (ii) offering the potential of a data management platform for heritage purposes.

Table 1. Users of heritage information, their competences, main tasks functions, GIS competences and access modality.

\begin{tabular}{|c|c|c|c|c|}
\hline STAKEHOLDERS & $\begin{array}{l}\text { COMPETENCES/ } \\
\text { USER PROFILE }\end{array}$ & $\begin{array}{l}\text { MAIN TASKS } \\
\text { FUNCTIONS }\end{array}$ & $\begin{array}{c}\text { GIS } \\
\text { COMPETENCES }\end{array}$ & ACCESS \\
\hline Municipality & $\begin{array}{l}\text { Architects } \\
\text { Civil Engineers } \\
\text { Conservators } \\
\text { Archaeologists }\end{array}$ & $\begin{array}{l}\text { Input information } \\
\text { View-Search-Extract } \\
\text { Data } \\
\text { Management }\end{array}$ & $\begin{array}{l}\text { Advanced GIS } \\
\text { users }\end{array}$ & $\begin{array}{l}\text { Desktop GIS } \\
\text { Web-GIS } \\
\text { (intranet) }\end{array}$ \\
\hline $\begin{array}{l}\text { National Institute } \\
\text { of Cultural } \\
\text { Heritage (INPC) }\end{array}$ & $\begin{array}{l}\text { Art historians } \\
\text { Conservators } \\
\text { Architects } \\
\text { Archaeologists }\end{array}$ & $\begin{array}{l}\text { Input information } \\
\text { View-Search-Extract } \\
\text { Data } \\
\text { Management }\end{array}$ & $\begin{array}{l}\text { No expertise with } \\
\text { the GIS }\end{array}$ & $\begin{array}{l}\text { Desktop GIS } \\
\text { Web-GIS } \\
\text { (intranet) }\end{array}$ \\
\hline Citizens & $\begin{array}{l}\text { Different } \\
\text { backgrounds }\end{array}$ & $\begin{array}{l}\text { View-Search-Extract } \\
\text { Data } \\
\text { Input monitoring } \\
\text { Information } \\
\text { maintenance } \\
\end{array}$ & $\begin{array}{l}\text { No expertise with } \\
\text { the GIS }\end{array}$ & $\begin{array}{l}\text { Web-GIS } \\
\text { (intranet- } \\
\text { restricted access) }\end{array}$ \\
\hline \multirow[t]{2}{*}{$\begin{array}{l}\text { UCuenca-Project } \\
\text { Citypres }\end{array}$} & $\begin{array}{l}\text { Students } \\
\text { Researchers }\end{array}$ & $\begin{array}{l}\text { Input information } \\
\text { View-Search-Extract } \\
\text { Data }\end{array}$ & $\begin{array}{l}\text { Advanced GIS } \\
\text { users }\end{array}$ & $\begin{array}{l}\text { Web-GIS } \\
\text { (intranet- } \\
\text { restricted access) }\end{array}$ \\
\hline & $\begin{array}{l}\text { Architects } \\
\text { Civil Engineers } \\
\text { GIS experts } \\
\text { Conservators } \\
\text { Staff vlirCPM } \\
\text { project }\end{array}$ & $\begin{array}{l}\text { Input information } \\
\text { View-Search-Extract } \\
\text { Data } \\
\text { Management } \\
\text { Analysis (monitoring } \\
\text { tool for others) }\end{array}$ & $\begin{array}{l}\text { Advanced GIS } \\
\text { users }\end{array}$ & $\begin{array}{l}\text { Desktop GIS } \\
\text { Web-GIS } \\
\text { (intranet) }\end{array}$ \\
\hline Tourists & $\begin{array}{l}\text { Different } \\
\text { backgrounds }\end{array}$ & $\begin{array}{l}\text { View-Search-Extract } \\
\text { Data } \\
\text { Input opinions of } \\
\text { tourists }\end{array}$ & $\begin{array}{l}\text { No expertise with } \\
\text { the GIS }\end{array}$ & $\begin{array}{l}\text { Web-GIS } \\
\text { (intranet- } \\
\text { restricted access) }\end{array}$ \\
\hline Researchers & $\begin{array}{l}\text { Architects } \\
\text { Civil Engineers } \\
\text { GIS experts } \\
\text { Conservators } \\
\text { Archaeologist }\end{array}$ & $\begin{array}{l}\text { View-Search-Extract } \\
\text { Data } \\
\text { Input of world-wide } \\
\text { research "experiences" } \\
\text { in heritage }\end{array}$ & $\begin{array}{l}\text { Advanced GIS } \\
\text { users }\end{array}$ & $\begin{array}{l}\text { Web-GIS } \\
\text { (intranet- } \\
\text { restricted access) }\end{array}$ \\
\hline
\end{tabular}

\subsection{Data sharing and users of the system}

Dissemination of heritage data is recognized as a most effective way to assure heritage conservation. This requires that the HIS has the capability that multiple users simultaneously can view, update or share, and manage information (Pepi, 2007). Therefore the data management system has to be very accessible, yet secure. Table 1 provides a structural overview of the main competences, tasks, and access modality of the users of heritage information, with application to the city of Cuenca. A schematic drawing of who provides and handles what information is depicted in Fig. 1 (Meyer et al., 2007). Data providers are the municipal departments directly and indirectly involved in heritage matters, the National Institute of Cultural Heritage, and university research units with activities in the heritage sector, such as the VLIR Project World Heritage City Preservation Management (vlirCPM) between the KU Leuven and the University of Cuenca. Some of the data providers are also using the stored information for the production of output in various forms and the conduct of risk analysis. To avoid conflicts in the system due to interferences between users requires proper control of all possible actions. This is modeled through use cases. An example is illustrated in the UML ${ }^{1}$ Use Case Diagram depicted in the lower part of Fig. 1. An important additional feature to be incorporated in the HIS, not

\footnotetext{
${ }^{1}$ UML: Unified Modeling Language
} 
shown in Fig. 1, is the preservation of the electronic information, an issue not consistently addressed in many information systems (Santana-Quintero and Addison, 2007).

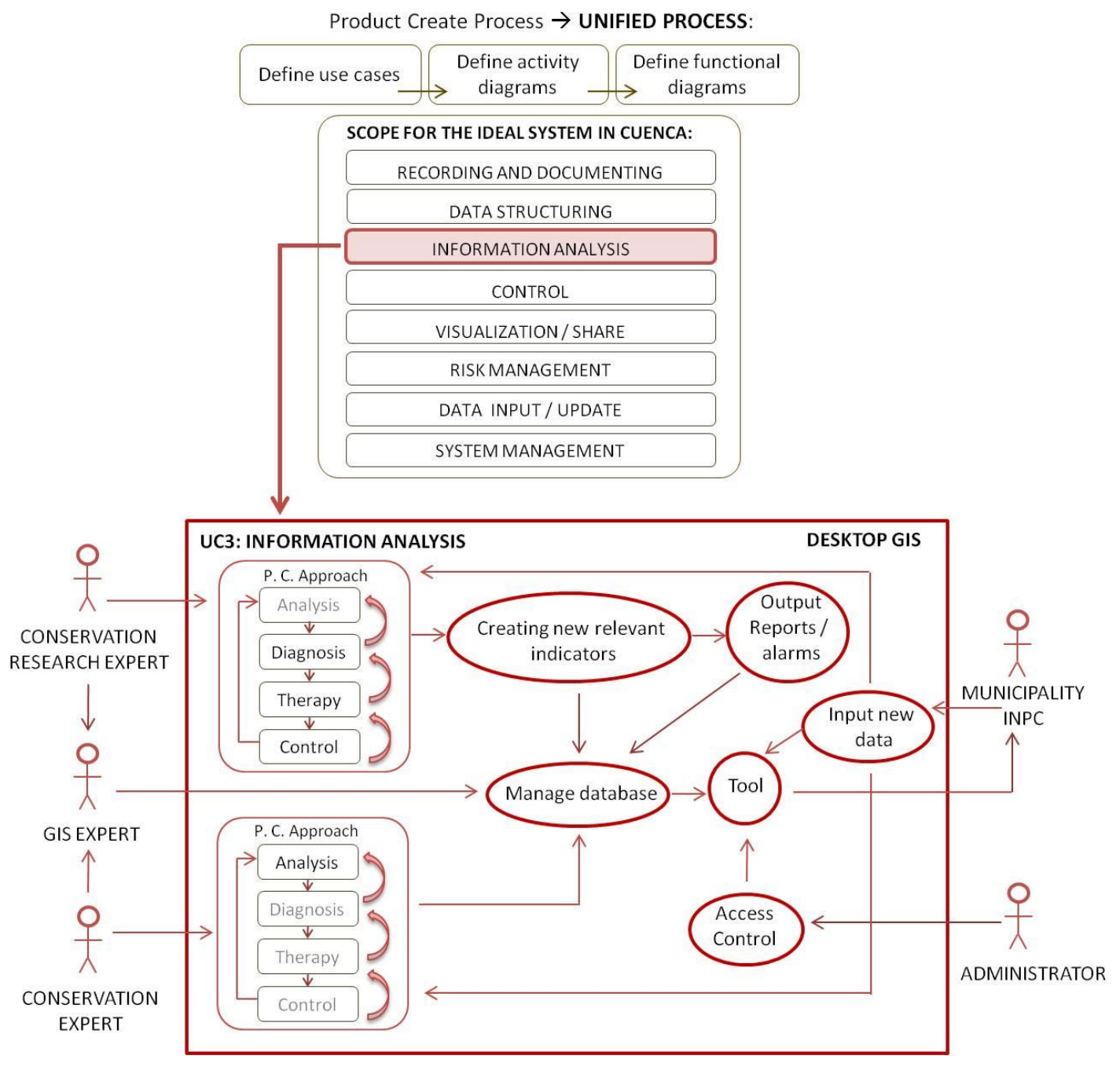

Figure 1. Scope of the ideal HIS for Cuenca (upper), and example of a Use Case diagram (UML) used a blueprint for the heritage information analysis (Heras, 2009).

\subsection{Heritage Management Platform}

\section{Architecture of the HIS}

The prototype of the Architecture of the Heritage Information System is based on the Three-Tier Architecture, a client-server in which the different processes are embedded in distinct layers. The first layer in the three-tier architecture corresponds to the Access, the second to the Application Management, and the third layer to the Data Management. The access layer in the conceptual HIS for the management of the heritage of the city of Cuenca contains two interfaces: (i) the desktop GIS, where the "users" will be able to input, manage and analyze heritage information, and (ii) web-GIS for the "other type of users", it means the common citizens or external users (e.g. researchers) who should have the possibility to access and use the heritage information generated in the system. The applications are performed and maintained in the second layer, the application management layer. In the particular case of the multitude and diversity of heritage elements in the city of Cuenca four modules are projected in this layer. The functionality of each of the modules are: 
$\checkmark$ The Catalog Services which mainly takes care of the display of information and the maintenance of the "metadata" in the system.

$\checkmark$ The objective of the Geo-Services module is the management, maintenance and display of images, maps and plans which require correct geo-referencing in line with the pre-established geographical datum. This module will also accomplish services related to solve queries, extract data, display and show features, multimedia, etc.

$\checkmark$ The Analysis Services constitutes a major module representing the intelligence kernel of the HIS, with tasks the evaluation and the derivation of logical decisions using stored heritage data.

$\checkmark$ The Access Control Services basically provides the rights to the system in function of the user qualification.

The third tier or the Data Management layer handles mainly the internal and external databases. In both cases special attention is given to the information reliability, according to Heras (2009) a crucial factor. The architecture of the HIS is shown in Fig. 2.

\section{$\underline{\text { Databases }}$}

The choice of database system in the HIS was constrained by the type of databases used in the institutions dealing with and managing heritage information, the type and nature of the data (very huge variety of data type even within the same institution), the knowledge and capacity level of personnel, and the technical problems most institutions face. The factors affecting the choice of database system are: the nature and volume of the data, database structure factors, lack of direct access, clumsy primary keys, data storage factors, related data dispersed available on hardware, business environment factors, limited data access and data access operations (Gillenson, 2005). Given previous and considering the nature of heritage data preference in the conceptual structure of the HIS was given to geodatabase (GDB) of Microsoft Access. This database guarantees the support of feature classes, images and attributes (stored information) of historic elements and small segments of larger heritage entities. It is evident given the probability that different users simultaneously consult the HIS that the system is implemented in a multi-user relational database (Oracle, MySQL, etc.), requiring the support of a computer engineer.

\section{Test and validation of the HIS: Maps / Analysis module}

Once the conceptual model and technical elements were identified, a small test was executed. The generated maps aim to support the decision-making through the analysis of different information such as risks, values, etc. The GIS analysis is a process which looks at geographic patterns in the data and at relationships between features (Andy, 1999). For the analysis phase ArcGIS Modelbuilder (ArcGIS 9.2) was used, enabling a systematically and documented processing of successive operations (addition, crop, proximity, etc.). The test analysis, as mentioned before, was planned at different scales permitting a comprehensive assessment of the current situation of heritage sites, including an analysis of the relation of these sites to a wider gamma of important factors in their heritage environment (threats/values).

Archaeological analysis (city scale). To guarantee the correct placement of the heritage sites within the archaeological context of the region, the analysis deals with: (i) the hypothetical archaeological map of the city covering the ancient settlements of the Cañaris and Incas in the territory, and (ii) the in 2006 updated cadastral map of the city. The analysis will provide the number and the location of parcels that require an archaeological prospection before the permission for an intervention can be issued. Figure 3 gives an overlay of the current cadastral map of the city and the area in which plots possess archaeological remains. A similar analysis can be conducted, for example between a hypothetical archaeological map and the map presenting the state of the roads in the historical centre of the city. The output of such an analysis will yield a map showing the roads that should be subjected to an archaeological survey before any intervention. 
MASKANA, Vol. 3, No. 1, 2012

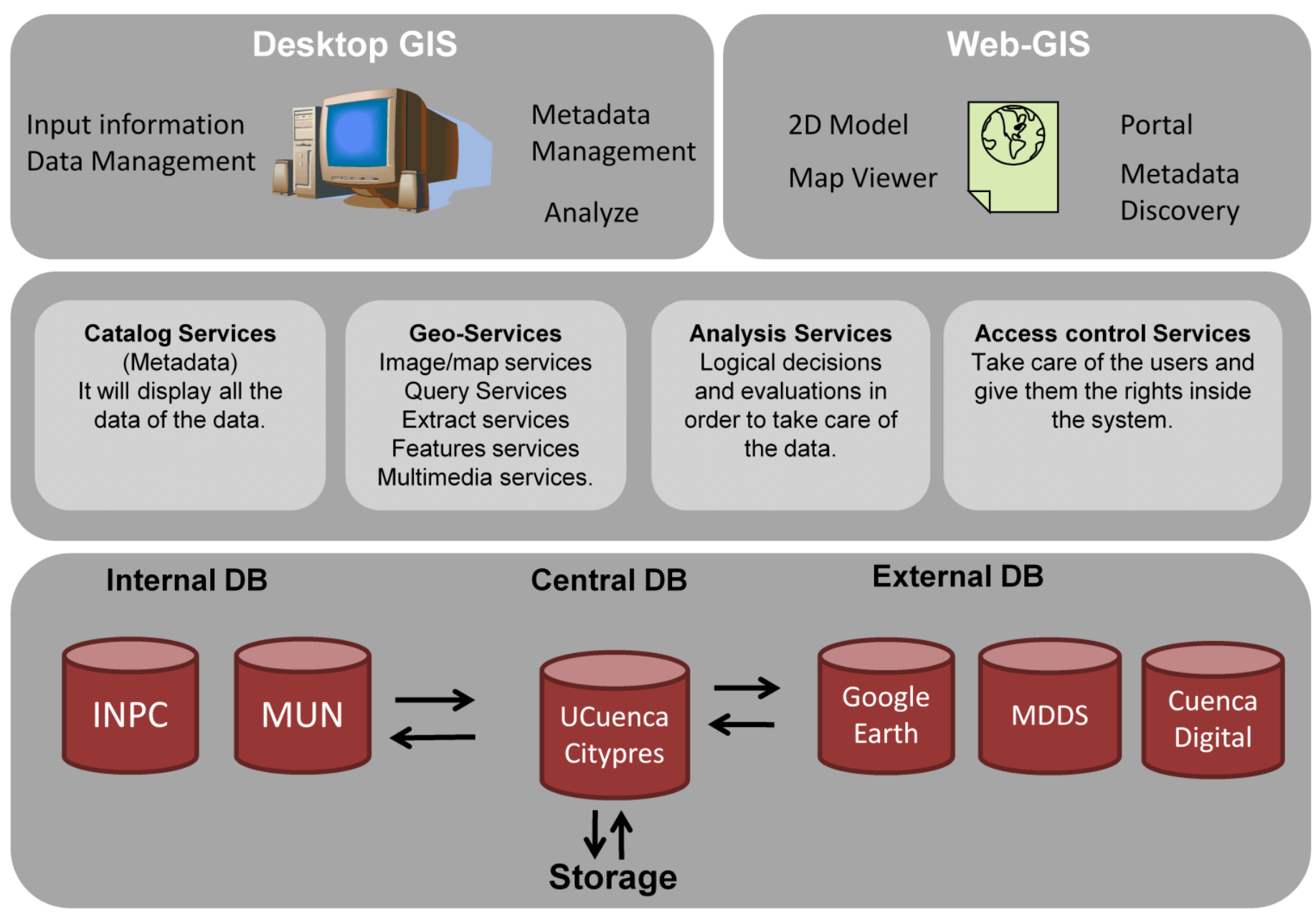

\section{Access}

Interface / Presentation

\section{Application \\ Management}

Takes care of the data that should be maintained in the databases and the users.

\section{Data Management \\ i) Internal DB.}

Input our own information.

ii) External DB.

Databases that are confident enouht ot thrust in its information.

Figure 2. Architecture of the Heritage Information System Cuenca (Heras, 2009). 


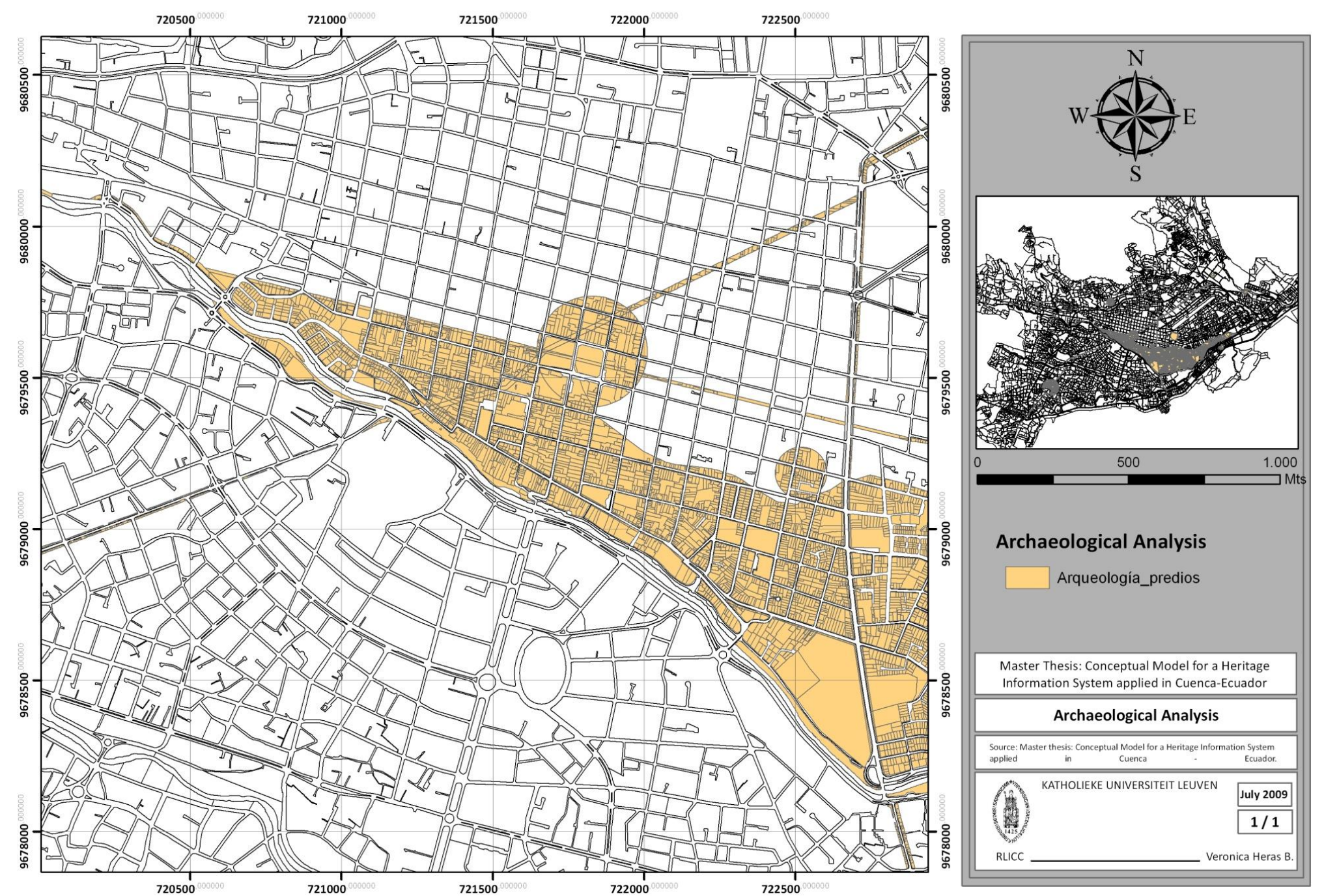

Figure 3. Map of Cuenca City depicting the result of the overlay analysis between the zone with archaeological settlements and the 2006 cadastral map (Heras, 2009). 


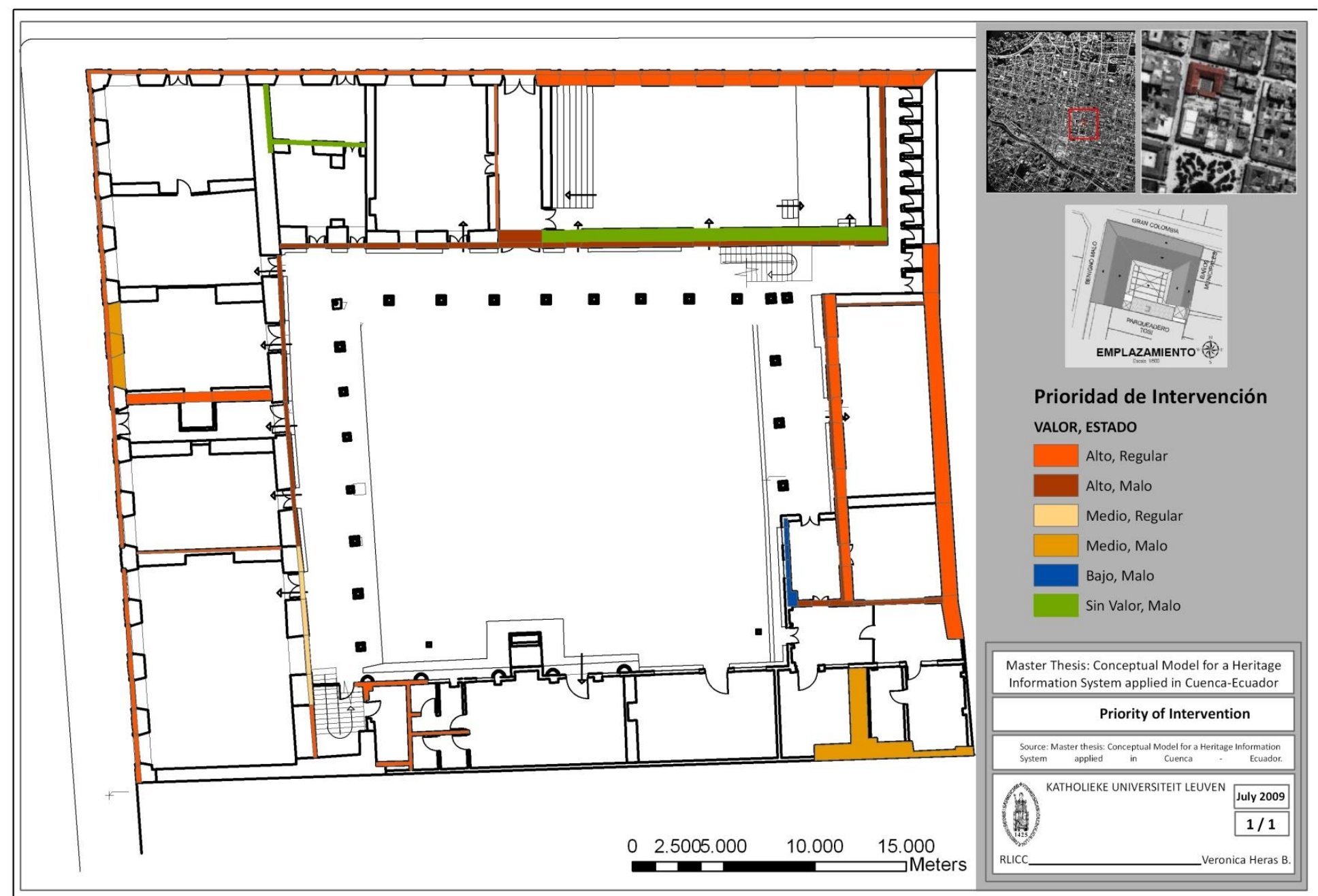

Figure 4. Ground floor of "La Escuela Central", depicting the walls that need priority intervention for its historical value and degraded state (Heras, 2009). 
Building elements analysis (detailed scale). The main added value of the research presented herein is the use of GIS at the level of small heritage elements, such as small structure, walls, roof, architectural decorations, etc. The HIS enables analyzing single components of a heritage building, and to place it in the wider cadre of the city of Cuenca, contributing to a more coherent preservation and conservation of single elements.

The proposed HIS is implemented on a heritage building of the city of Cuenca called the "Escuela Central". The building consists of a 2-story house, featuring three important historical periods linked to different uses. Figure 4, depicting a top view, it shows the ground floor of the building. The building elements are represented by polygons, lines and points, and linked to the geodatabase. Apart from expressing geographical features as vectors within the GIS, the analysis focused on the evaluation of heritage elements requiring urgent attention due to a combination of factors, such as: heritage values (Stovel, 2007), risks assessment (Waller, 1995) and the state of conservation (World Heritage Committee, 2007). The result shown in Fig. 4 will orient the tenant, owner and city heritage managers to focus joint efforts on those parts or elements that are most at risk and most valued.

\section{CONCLUSIONS}

Introduction of the preventive conservation concept in a Heritage Information System opens the possibility to better monitor and manage heritage elements, and this within the archaeological context of the site. The case study, the HIS for Historic Centre of Cuenca showed the capabilities of such a system, able of analyzing simultaneously different types of data, at different scales. Moreover, it provides ad-hoc monitoring possibilities enhancing the ability to share information, documentation and decision-making. Whereas the presented analysis is a theoretical exercise the next steps in the research after some preliminary tests, to identify if the conceptual design of the data information system needs further improvements, will be the construction and implementation of the information system. It is evident that parallel to the development of the system didactic manuals are drafted and that personnel of the different institutions dealing with heritage preservation and conservation are subjected to training in the HIS. Last but not least the HIS enables the inclusion and exploration of new tools in response to future needs, such as the identification of risks, the development of mitigation strategies and control actions, among others, defining for each solution alternatives and balancing the estimated costs to the available financial resources for heritage conservation, assisting the decision-making process. Given the wider context in which measures can be identified, the HIS system will assure that in future the heritage managers of the city of Cuenca will define conservation measures and strategies coherent with the cultural and historic value(s) of the World Heritage character of the city.

\section{ACKNOWLEDGEMENTS}

Funding for the research was provided by the Interuniversity Cooperation Program of the Flemish Interuniversity Council (VLIR-IUC), Belgium. The study was executed within the project "World Heritage City Preservation Management", a project between the Raymond Lemaire International Centre for Conservation, Katholieke Universiteit Leuven (KU Leuven), Leuven-Belgium, and the Faculty of Architecture of the University of Cuenca, Cuenca-Ecuador. The authors kindly acknowledge to the municipality of the City of Cuenca for providing access to the multitude of data, and are grateful to Ximena Salazar for her assistance with the development of the HIS. Finally we like to thank Dr. Jan Feyen for his review and criticism and editorial support in the preparation of the final manuscript. 


\section{REFERENCES}

Andy, M., 1999. The ESRI Guide to GIS Analysis, Vol. 1: Geographic Patterns \& Relationships, ESRI California, $190 \mathrm{pp}$.

Bansal, V.K., M. Pal, 2009. Construction schedule review in GIS with a navigable 3-D animation of project activities. Int. J. Project Manage., 27, 532-542.

Heras, V., 2009. Development of a conceptual Heritage Information System. Case of Study: Cuenca Ecuador. MSc. Thesis. Raymond Lemaire International Center for Conservation (RLICC), Faculty of Engineering, KU Leuven, Leuven, Belgium, $250 \mathrm{pp}$.

Gillenson, M.L., 2005. Fundamentals of Database Management Systems. University of Memphis, Textbook. John Wiley \& Sons, 350 pp.

ICOMOS, 1964. The Venice Charter. Proceedings of the $2^{\text {nd }}$ International Congress of Architects and Technicians of Historic Monuments, Venice, Italy, 978 pp.

Letellier, R., 2007. Recording, Documentation, and Information Management for the Conservation of Heritage Places. Vol. 1: Guiding Princiles. The Getty Conservation Institute, Los Angeles, 174 pp.

Meul, V., A. Stulens, 2010. The integral approach of Monumentenwacht Vlaanderen: a model for implementing participatory preventive conservation for historic interiors. In: A Holistic View for Historic Interiors, ICOM-CC Interim Meeting, Rome, Italy, 12 pp.

Meyer, E., P. Grussenmeyer, J.P. Perrin, A. Durand, P.Drap, 2007. A web information system for the management and the dissemination of Cultural Heritage data. J. Cultural Heritage, 8, 396-411.

Pepi, R.M., 2007. The digital age. Building Conservation Associates, New York. Downloadable from http://www.bcausa.com/pdf/news/TB_DigitalAge.pdf.

PRECOMOS, 2007. UNESCO Chair Launch-Leuven, RLICC - KULeuven, p. 85-99.

PRECOMOS, 2010. I Encuentro PRECOMOS, II Taller Andino para gestores de sitios inscritos o no en la Lista de Patrimonio Mundial, Proyecto vlirCPM, Universidad de Cuenca, p. 54-8.

Santana-Quintero, M., A.C. Addison, 2007. Digital tools for heritage information management and protection: The need of training. In: Wyeld, S.K.T.G., M. Docherty (Eds.), 13th International Conference on Virtual Systems and Multimedia (VSMM), Brisbane, Australia, p. 35-46.

Santana-Quintero, M., O. Vileikis, 2011. Heritage Recording and Information Management in the Digital Age (SMARTdoc-heritage). Change over Time, 1(2), 156-164.

Stovel, H., 2007. Effective use of authenticity and integrity as world heritage qualiifying conditions. City \& Time, 2(3), $16 \mathrm{pp}$.

Stulens, V.M.a.A., 2000. The integral approach of Monumentenwacht Vlaanderen: a model for implementing parcipatory preventive conservation for historic interiors. Monumentenwacht Vlaanderen vzw, Antwerp, Belgium.

Pepi, R.M., 2007. Building maintenance. In: The Digital Age, Vol. 2010. Building Conservation Associates Inc., New York, 3 pp.

Waller, R.R., 1995. Risk management applied to preventive conservation. In: Rose, C.L., C.A. Hawks, H.H. Genoways (Eds.). Storage of natural history collections: A preventive conservation approach. Society for the Preservation of Natural History Collections, p. 21-27.

World Heritage Committee, 2007. Convention concerning the protection of the world cultural and natural heritage. $31^{\text {st }}$ Session WHC, UNESCO, Chistchurch, New Zeland, 267 pp. 